\title{
A Study on the Gene Expression of Adipogenic Regulators by an Herbal Composition
}

\author{
Haeyong Lee, Ryunhwa Kang, Sungmin Bae, Soo Ahn Chae', Jung Ju Lee', Dong-Jin Oh², \\ Sukwon Park, Soo Hyun $\mathrm{Cho}^{4}$, Yae Jie Shim ${ }^{5}$ and Yoosik Yoon* \\ Department of Microbiology, ${ }^{1}$ Pediatrics, ${ }^{2}$ Internal Medicine, ${ }^{3}$ Radiation Oncology, ${ }^{4}$ Family Medicine, Chung-Ang University College of Medicine, \\ Seoul 156-756, Korea \\ ${ }^{5}$ Departement of General Education, Seoul Women's University, Seoul 139-774, Korea
}

Received February 2, 2010 /Accepted March 10, 2010

\begin{abstract}
In our previous study, it was reported that an herbal mixture, $\mathrm{SH} 21 \mathrm{~B}$, inhibits fat accumulation and adipogenesis both in vitro and in vivo models of obesity. SH21B is a mixture composed of seven herbs: Scutellaria baicalensis Georgi, Prunus armeniaca Maxim, Ephedra sinica Stapf, Acorus gramineus Soland, Typha orientalis Presl, Polygala tenuifolia Willd, and Nelumbo nucifera Gaertner (Ratio 3:3:3:3:3:2:2). The aim of this study was to investigate the detailed molecular mechanisms of the effects of SH21B on various regulators of the adipogenesis pathway. During the adipogenesis of 3T3-L1 cells, SH21B significantly decreased the expression levels of central transcription factors of adipogenesis, such as peroxisome proliferator-activated receptor (PPAR) $y$ and CCAAT/enhancer binding protein (C/EBP) $\alpha$. To elucidate the detailed molecular mechanism of the anti-adipogenic effects of SH21B, we examined the expression levels of the various pro-adipogenic or anti-adipogenic regulators of adipogenesis upstream of PPAR $\gamma$ and C/EBPa. The mRNA levels of Krox20 and Kruppel-like factor (KLF) 15, which are pro-adipogenic regulators, were significantly down-regulated by SH21B treatment, whereas the mRNA levels of C/EBP $\beta$ and KLF5 were not changed. KLF2 and C/EBP homologous protein (CHOP), which are anti-adipogenic regulators, were significantly up-regulated by $\mathrm{SH} 21 \mathrm{~B}$ treatment. These results suggest that the molecular mechanism of the anti-adipogenic effect of SH21B involves both the down-regulations of pro-adipogenic regulators, such as Krox20 and KLF15, and the up-regulations of anti-adipogenic regulators, such as KLF2 and $\mathrm{CHOP}$, which results in the suppression of central transcription factors of adipogenesis including PPAR $\gamma$ and $C / E B P \alpha$.
\end{abstract}

Key words : Adipogenesis, SH21B, Krox20, KLF15, KLF2, CHOP

\section{서 론}

비만은 지방세포와 지방조직의 비정상적인 증식과 성장에 의한 결과로써 당뇨, 심혈관 질환 그리고 암 등의 다양한 질병 을 유발한다[18]. 비만과 밀접한 관계를 가지는 지방세포형성 (adipogenesis)은 세포 형태의 변화, 호르몬 민감성의 변화, 유 전자 및 단백질 발현의 변화 등이 복합적으로 작용하면서 유 도된다[23]. 지방세포형성 및 분화의 in vitro 연구에 일반적으 로 사용되는 3T3-L1 전지방세포는 여러 호르몬들과 세포분열 유도물질 등에 의해 지방세포형성 요건이 충족되면 지방세포 로 분화된다[16]. 지방세포의 분화는 주요 조절자인 CCAAT/ enhaner binding protein $(\mathrm{C} / \mathrm{EBP}) \mathrm{s}$ 와 peroxisome proliferator-activated receptor (PPAR) $\gamma$ 에 의해 조절되는데, 분 화초기에는 $\mathrm{C} / \mathrm{EBP} \beta$ 가 높게 발현되고 분화후기에는 $\mathrm{C} / \mathrm{EBPa}$ 와 PPAR $\gamma$ 가 높게 발현된다[20]. 지방세포형성의 핵심전사인 자(central transcription factor) $\mathrm{C} / \mathrm{EBPa}$ 와 $\mathrm{PPAR} \gamma$ 는 상호작 용하면서 서로의 발현에 상승효과를 일으키고 그 결과로 adi-

*Corresponding author

Tel : +82-2-820-5767, Fax : +82-2-820-5767

E-mail : thanks@cau.ac.kr ponectin (ADIPOQ), solute carrier family 2, member 4 (SLC2A4) 등을 포함한 adipogenesis의 최종마커(terminal marker)의 발현을 유도한다[7,9]. 또한, C/EBPa와 PPAR $\gamma$ 는 adipogenesis pathway에서 상위에 위치한 Krox20, Kruppel- like factor $(\mathrm{KLF}) 5, \mathrm{KLF} 15$ 등과 같은 지방세포형성 유도 조절자 (pro-adipogenic regulator)와 $\mathrm{C} / \mathrm{EBP}$ homologous protein $(\mathrm{CHOP}), \mathrm{C} / \mathrm{EBP} \gamma, \mathrm{KLF} 2$ 등과 같은 지방세포형성 억제 조절 자(anti-adipogenic regulator)들에 의해 조절되어진다[20].

최근, 항암, 항염증, 항비만 등에 대한 생약성 물질들의 효능 에 대한 연구가 많이 보고되고 있다. SH21B는 황금(Scutellaria baicalensis Georgi), 행인(Prunus armeniaca Maxim), 마황 (Ephedra sinica Stapf), 석창포(Acorus gramineus Soland), 포황 (Typha orientalis Presl), 원지(Polygala tenuifolia Willd), 하엽 (Nelumbo nucifera Gaertner)의 혼합(비율 3:3:3:3:3:2:2)으로 이 루어진 생약복합물로 최근 본 연구진에 의해 이루어진 선행연 구의 결과 3T3-L1세포 및 고지방식이 마우스 동물모델에서 adipogenesis 억제를 통한 지방축적 억제효과가 있음이 규명 되었다[11]. 본 연구에서는 3T3-L1 지방세포에서 SH21B가 미 치는 adipogenesis 억제에 대한 보다 상세한 분자적 메커니즘 을 규명하기 위하여 adipogenesis를 조절하는 다양한 유전자 
의 발현을 시간의 흐름에 따라 분석하였다.

\section{재료 및 방법}

\section{SH21B의 제조 및 표준화}

$\mathrm{SH} 21 \mathrm{~B}$ 의 제조 및 표준화 과정은 선행 연구논문에서 상세하 게 제시되었으며 이를 요약하면 다음과 같다[11]. 원재료가 되 는 생약은 성일바이오엑스(Hwasung, Korea)에서 구입하였 다. 황금, 행인, 마황, 석창포, 포황, 원지, 하엽의 7 가지 생약을 3:3:3:3:3:2:2의 비율로 혼합하여 $30 \%$ 에탄올에서 3시간씩 2회 추출한 후, 에탄올과 동일한 부피의 부탄올을 가하여 2시간 동안 추출한 다음 부탄올 층을 따로 분획하였다. 이후 부탄올 분획물을 증발농축기를 이용하여 용매를 증발시키고 분말상 태인 SH21B엑스를 얻었다. 최종적으로 얻어진 SH21B엑스의 양은 추출 전 생약 원료 양의 $4.9 \%$ 였다(w/w). SH21B의 추출 후, thin layer chromatography를 사용하여 7종류의 생약 물질 의 성분을 조사하고 high performance liquid chromatography 를 사용하여 구성 물질의 양을 측정한 결과, $11.4 \%$ 와 $4.2 \%$ 를 각각 차지하는 바이칼린(baicalin)과 아미그달린 (amygdalin)이 SH21B의 주요 성분으로 분석되었다.

\section{세포 배양 및 시약}

실험에 사용된 3T3-L1 세포(preadipocyte)는 ATCC (American type culture collection, Manassas, VA, USA)에서 구입하여 Dulbecco's modified Eagle's medium (DMEM)에 $10 \%$ calf serum, $100 \mu \mathrm{g} / \mathrm{mL}$ streptomycin, and 100 units $/ \mathrm{mL}$ penicillin 과 함께 $37^{\circ} \mathrm{C}, 5 \% \mathrm{CO}_{2}$ 세포 배양기에서 배양하였다. 다른 시약들은 Sigma Chemical Co. (St. Louis, MO, USA)에서 구입하였다.

\section{Adipogenesis 유도}

3T3-L1 세포는 phosphate buffered saline (PBS) 용액으로 씻어준 후, 1 2x10 cells/ml을 6 well-plate에 세포밀도가 $100 \%$ 가 될 때까지 배양하였다. 2 일 후(day 0), $10 \%$ fetal bovine serum (FBS)을 포함한 DMEM에 $1 \mu \mathrm{g} / \mathrm{ml}$ insulin, 0.25 $\mu \mathrm{M}$ dexamethasone 그리고 $0.5 \mathrm{mM}$ 3-isobutyl-1-methylxanthine이 첨가된 differentiation-induction medium (분화 유도 배지)로 교체하여 48 시간 처리하였다. 그 후 2 일 간격으 로 $10 \% \mathrm{FBS}$ 를 포함한 새 배지에 $1 \mathrm{\mu g} / \mathrm{ml}$ insulin이 첨가된 differentiation-maintenance medium (분화 유지 배지)로 교 체되었다. Adipogenesis의 진행과정에서SH21B의 효능을 확 인하기 위해, 분화 유도 배지와 분화 유지 배지를 첨가할 때 $\mathrm{SH} 21 \mathrm{~B}$ 를 함께 처리하였다.

\section{Total RNA 추출}

Total RNA는 acid-phenol 추출법을 이용한 RNeasy kit
(Qiagen, Hilden, Germany)를 사용하여 제시된 편람에 따라 분리 정제되었다. 추출된 total RNA는 분광광도계를 이용하 여 optical density $(\mathrm{OD})$ 값을 측정하고 역전사(reverse transcription) 반응을 진행할 때까지 $-80^{\circ} \mathrm{C}$ 에 보관하였다.

\section{Real-Time polymerase chain reaction (PCR)}

$1 \mu \mathrm{g}$ 의 total RNA는 cDNA Reverse Transcription Kit (Applied Biosystems, Inc., Foster City, CA, USA)를 이용하여 역전사 하였다. Real-time PCR은 7000 Real-Time PCR System (Applied Biosystems, Inc., Foster City, CA, USA) 장비를 사 용하여 진행되었다. $\mathrm{PCR}$ 은 다음의 조성으로 최종 반응 부피 를 $20 \mu 1$ 로 준비하여 3반복 하였다: TaqMan gene expression master mix, $250 \mathrm{nM}$ TaqMan Probe, $2 \mu \mathrm{M}$ 의 각 primer, 2 $\mu \mathrm{l}$ 의 cDNA. 적정 조성으로 혼합된 반응물질은 효소를 활성화 시키기 위해 $95^{\circ} \mathrm{C}$ 에서 10 분간 반응시킨 후, $95^{\circ} \mathrm{C}$ 에서 15 초와 $60^{\circ} \mathrm{C}$ 에서 1 분으로 구성된 40 cycle을 진행하였다. Real-Time $\mathrm{PCR}$ 에 사용된 primer는 Applied Biosystems 사의 assay on demand gene expression 제품을 구매하여 사용하였다 (Applied Biosystems, Inc., Foster City, CA, USA). Endogenous control는 Gustafson과 Smith를 참고로 $18 \mathrm{~S}$ rRNA를 사용하였 다[6]. 각 샘플에 대한 표적유전자의mRNA 수준은 동일한 샘 플 내의 $18 \mathrm{~S} \mathrm{rRNA}$ 에 의해 표준화되었고, 표준화 된 샘플들의 값은 전지방세포(day 0)의 값을 기준으로 Ct method에 의해 비교되었다[13].

\section{통계학적 분석}

모든 실험결과는 SPSS ver. 14.0 프로그램(SPSS, Chicago, $\mathrm{IL}, \mathrm{USA})$ 을 이용하여 평균(mean) \pm 표준오차(S.E.)로 나타냈다. $\mathrm{SH} 21 \mathrm{~B}$ 가 첨가된 군과 첨가되지 않은 군, 두 군 사이의 비교에 대한 통계의 유의성은 unpaired t-test에 의해 검증되었다.

\section{결과 및 고찰}

\section{중성지방 축적 및 최종마커 유전자 발현}

지방세포형성, 비만 및 인슐린과 관련된 연구 등에서 일반적 으로 사용되는 3T3-L1 전지방세포는 insulin, dexamethasone 및 isobutyl methyl xanthine (IBMX) 등의 분화유도 물질이 첨가되면 지방세포로 분화되면서 세포질 내에 중성지방이 형 성되고 축적되는 것으로 알려져 있다[20]. 정상적인 분화가 진 행되었음을 나타내는 중성지방의 형성은 그 축적 정도에 따라 분화의 척도가 될 수 있으며 Oil Red O 염색을 통해 시각화될 수 있다. 그림 $1 \mathrm{~A}$ 는 전지방세포가 지방세포로 분화됨에 따라 Oil Red O 시약에 의해 붉게 염색된 중성지방이 증가됨을 보 여준다. 또한 $100 \mu \mathrm{g} / \mathrm{ml} \mathrm{SH21B}$ 의 첨가에 의해 중성지방이 크게 감소됨으로써 SH21B의 지방세포형성 억제 효과를 보여 준다. SH21B에 의한 지방세포형성 억제효과는 본 연구진의 
선행 연구에서 보다 상세하게 규명된 바 있다[11].

$\mathrm{ADIPOQ}$ 수용체(AdipoR)와 결합하여 에너지 대사와 인슐린 신호경로(insulin pathway)를 조절하는 아디포카인(adipokine) 으로 잘 알려진 $\mathrm{ADIPOQ}$ 는 지방세포형성의 대표적인 최종마 커이다[10]. Real-time PCR의 결과에서, $\mathrm{ADIPOQ}$ 의 mRNA는 분화 전과 비교하여 분화 후에서 15,000 배 이상 증가되었다가 $\mathrm{SH} 21 \mathrm{~B}$ 에 의해 급격하게 감소되었다(Fig. 1B) SLC2A4는 GLUT4 로 불리며 당 수송(glucose transport)과 지질대사에서 중요한 기능을 하는 것으로 알려져 있다[22]. 지방세포형성의 최종마 커인 SLC2A4 역시 분화 전과 비교하여 분화 후에서 $\mathrm{mRNA}$ 발현이 20배 이상 크게 증가하였다가 $\mathrm{SH} 21 \mathrm{~B}$ 에 의해 유의하게 감소되었다. 이러한 결과들은 SH21B가 지방세포형성을 억제 함으로써 중성지방의 축적 및 최종마커의 mRNA 발현을 저해 함을 제시한다.

지방세포형성 핵심전사인자의 유전자 발현

지방세포형성 및 중성지방의 축적 그리고 최종마커의 발현 은 핵심전사인자인 $\mathrm{C} / \mathrm{EBPa}$ 와 $\operatorname{PPAR} \gamma$ 에 의해 조절된다
$[12,17,21]$. Nuclear hormone receptor superfamily에 속하는 $\operatorname{PPAR} \gamma$ 는 지방세포의 분화 조절과 지방조직의 형성 뿐 아니 라, 당뇨 등과 같은 각종 성인병에서도 중요한 기능을 하고 있다[1,24]. 마우스의 섬유아세포에서 PPAR $\gamma$ 를 과다 발현할 경우, 지방세포의 분화가 온전히 유도됨이 보고되었고[26], $\operatorname{PPAR} \gamma$ 가 결핍된 마우스에서는 정상적인 비만세포형성이 유 도되지 않고 인슐린대사에 문제가 발생하는 것으로 보고되었 다[14,27]. 본 연구의 real-time PCR 결과에서, $\operatorname{PPAR} \gamma$ 의 mRNA 발현은 분화 전과 비교하여 분화 후에서 10 배 이상 증가하였다가 $\mathrm{SH} 21 \mathrm{~B}$ 의 첨가에 의해 유의하게 감소되었다 (Fig. 2A). C/EBPa는 PPAR $\gamma$ 와 상호작용을 통해 서로의 발현 을 증가시켜 지방세포의 분화를 유도하고 최종마커의 발현을 증가시킨다. Freytag 등은 다양한 섬유아세포에 $\mathrm{C} / \mathrm{EBPa}$ 를 과 다발현시켜 adipogenesis를 유도함으로써 $\mathrm{C} / \mathrm{EBPa}$ 의 기능 및 중요성을 증명하였다[4]. 그림 $2 \mathrm{~B}$ 에서 $\mathrm{C} / \mathrm{EBPa}$ 는 분화가 진행 되면서 15 배 가까이 크게 증가하였다가 $\mathrm{SH} 21 \mathrm{~B}$ 에 의해 유의하 게 감소하였다. 이러한 결과들은 SH21B가 adipogenesis의 두 핵심 조절자인, $\mathrm{C} / \mathrm{EBPa}$ 와 $\mathrm{PPAR} \gamma$ 의 발현을 억제함으로써

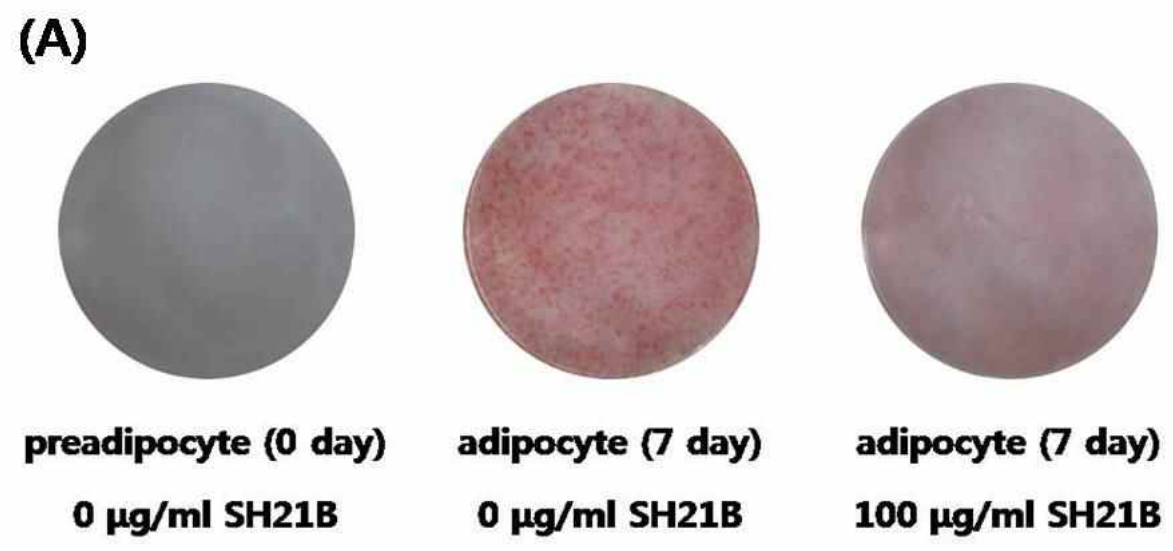

\section{Terminal markers}

(B)

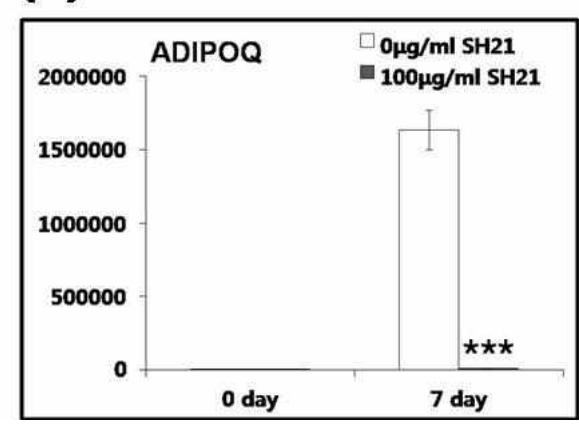

(C)

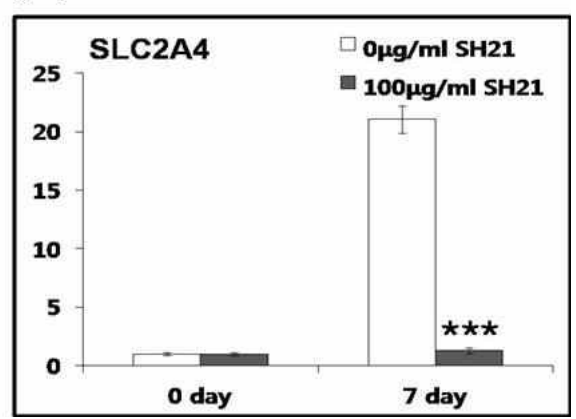

Fig. 1. Anti-adipogenic effect of SH21B. Oil Red O staining shows inhibitory effects of SH21B on lipid droplet formation (A). mRNA expression of ADIPOQ (B) and SLC2A4 (C) which are terminal markers in 3T3-L1 cells differentiated for 0 and 7 day with or without $100 \mu \mathrm{g} / \mathrm{ml} \mathrm{SH21B}$ treatment. ${ }^{* * *}$ p, 0.001 compared with untreated adipocytes. 


\section{Central transcription factors}

\section{(A)}

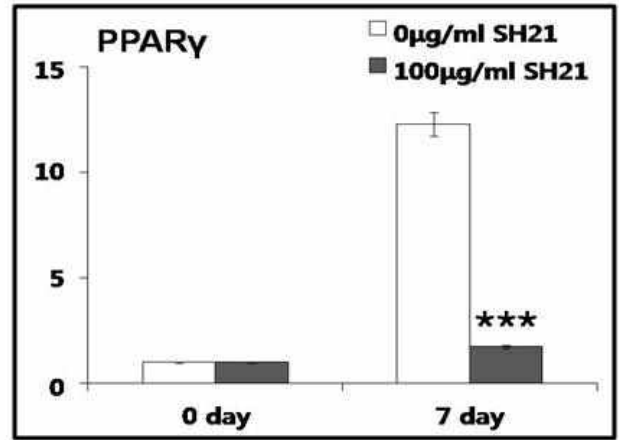

(B)

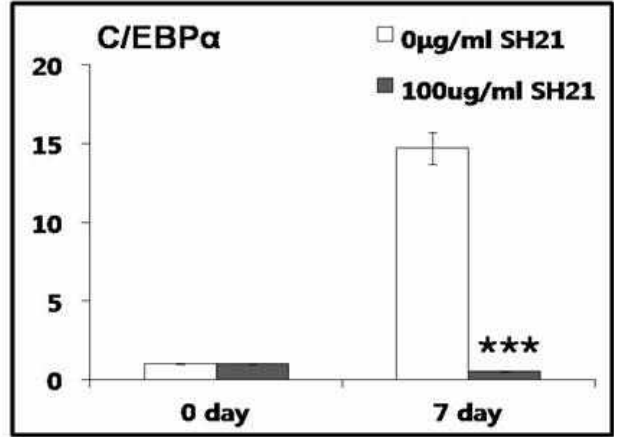

Fig. 2. Effects of platycodin $\mathrm{D}$ on the mRNA expressions of the central transcription factors of adipogenesis. mRNA expression of PPAR $\gamma$ and C/EBPa in 3T3-L1 cells differentiated for 0 and 7 day with or without $100 \mu \mathrm{g} / \mathrm{ml} \mathrm{SH21B} \mathrm{treatment.}$ *** $p$, 0.001 compared with untreated adipocytes.

최종마커의 발현을 감소시키고 중성지방의 축적을 저해함을 제시한다.

\section{지방세포형성 유도조절자의 유전자 발현}

Adipogenesis는 여러 지방세포형성 억제조절자와 지방세 포형성 유도조절자의 조절에 의해 이루어진다[20]. CHOP, KLF2 등은 adipogenesis를 억제하는 지방세포형성 억제조절 자로써 전지방세포에서 높게 발현되어 있다가 분화유도 물질 에 의해 분화가 유도되면 그 발현이 크게 억제되는 것으로 알려져 있다. 이와는 반대로 Krox20, C/EBP , KLF5 및 KLF15 와 같은 지방세포형성 유도조절자들은 분화유도 물질에 의해 발현이 증가되면서 분화를 유도한다. PPAR $\gamma$ 와 $\mathrm{C} / \mathrm{EBPa}$ 는 상위에 위치하는 다양한 지방세포형성 억제조절자와 지방세 포형성 유도조절자에 의해 조절되기 때문에, $\operatorname{PPAR} \gamma$ 와 $\mathrm{C} / \mathrm{EBPa}$ 의 상위 조절자의 유전자 발현에 대한 연구가 요구되 었다.

지방세포형성 유도 조절자 중에서 $\mathrm{C} / \mathrm{EBP} \beta$ 는 대표적인 $\mathrm{C} / \mathrm{EBPa}$ 와 $\mathrm{PPAR} \gamma$ 의 상위조절자이며 분화 초기에 크게 발현 되는 것으로 알려져 있다. $\mathrm{C} / \mathrm{EBP} \beta$ 를 제거한 마우스의 경우 지방세포의 분화 및 지방조직이 정상적으로 형성되지 않는 것으로 보고되었다[25]. SH21B가 C/EBPB에 주는 효과를 살 펴보기 위하여 분화 시간 별로 $\mathrm{C} / \mathrm{EBP} \beta$ 의 $\mathrm{mRNA}$ 발현을 측정 한 결과, $\mathrm{C} / \mathrm{EBP} \beta$ 는 $\mathrm{SH} 21 \mathrm{~B}$ 의 첨가 유무에 따라 초기와 후기 분화에서 그 발현이 크게 변하지 않았다(Fig. $3 \mathrm{~A}$ ). 이러한 결과 는 $\mathrm{SH} 21 \mathrm{~B}$ 에 의한 지방세포형성 억제 효능이 $\mathrm{C} / \mathrm{EBP} \beta$ 에 비의 존적임을 제시한다. 또 다른 지방세포형성 유도조절자인, 전 사인자 Krox20은 지방 조직과 3T3-L1의 초기분화에는 높게 발현되지만 분화가 완전히 이루어진 3T3-L1 세포에서는 발현 되지 않는다[2]. 또한 Krox20은 C/EBP 3 의 발현을 증가시킴으 로써 adipogenesis을 조절함과 동시에 $\mathrm{C} / \mathrm{EBP} \beta$ 와 비의존적으
로 adipogenesis을 조절한다고 보고하고 있다[2]. 본 연구에서 Krox20의 mRNA 발현은 adipogenesis 과정 중에 뚜렷하게 증가하지만SH21B에 의해 유의하게 억제되었다(Fig. $3 \mathrm{~B}$ ). 그림 $3 \mathrm{~A}$ 에서 $\mathrm{C} / \mathrm{EBP} \beta$ 의 $\mathrm{mRNA}$ 발현이 $\mathrm{SH} 21 \mathrm{~B}$ 에 의해 변화가 없었 기 때문에, $\mathrm{SH} 21 \mathrm{~B}$ 첨가에 의한 Krox20의 mRNA 변화는 $\mathrm{C} / \mathrm{EBP} \beta$ 와는 비의존적으로 지방세포형성에 관여한다고 생각 되어진다. KLF는 세포의 발생, 분화 및 활성을 조절하는 중요 한 전사 인자로 알려져 있다[8]. KLF family에 속하는 KLF15 와 KLF5는 지방세포형성 유도조절자로써 지방세포형성에 깊 게 관련되는 것으로 알려져 있다[15]. PPAR $\gamma$ 의 상위 조절자 인 $\mathrm{KLF} 5$ 와 $\mathrm{KLF} 15$ 는 각각 초기, 후기 분화에서 $\operatorname{PPAR} \gamma$ 의 promoter에 결합하여 전사를 조절한다 $[5,19]$. 본 연구에서 KLF15의 mRNA 발현은 adipogenesis 과정 중에 후기까지 크 게 증가하지만 $\mathrm{SH} 21 \mathrm{~B}$ 의 처리에 의해 유의적으로 억제되었다 (Fig. $3 \mathrm{C}$ ). 이와는 달리 KLF5의 mRNA 발현은 SH21B에 의해 영향을 받지 않았다(Fig. 3D). 지방세포형성 유도조절자인 $\mathrm{KLF} 5$ 는 $\mathrm{C} / \mathrm{EBP} \beta$ 에 의해 조절된다고 알려져 있다. $\mathrm{SH} 21 \mathrm{~B}$ 의 첨가에 의해 영향을 받지 않은 KLF5의 mRNA 발현 결과는 그림 $3 \mathrm{~A}$ 에서의 $\mathrm{C} / \mathrm{EPB} \beta$ 의 결과로 설명될 수 있다. 이러한 결 과들은 $\mathrm{SH} 21 \mathrm{~B}$ 의 지방세포형성 억제효과가 여러 지방세포형 성 유도유전자 중 Krox20과 KLF15의 발현을 억제함으로써 $\operatorname{PPAR} \gamma$ 와 $\mathrm{C} / \mathrm{EBPa}$ 의 유전자 발현을 조절하는 것임을 나타낸다.

\section{지방세포형성 억제조절자의 유전자 발현}

Adipogenesis pathway에서 KLF는 핵심조절자인 $\operatorname{PPAR} \gamma$ 를 타깃으로 하고 있다. KLF15, KLF5와는 달리 KLF2는 지방 세포형성을 억제하는 조절자로 알려져 있다. KLF2는 지방세포 가 분화되기 전에 높게 발현되어 있다가 분화가 시작되면서 급격하게 감소된다[1]. 본 연구에서 KLF2의 유전자 발현은 분 화가 진행되면서 감소하였다가 $\mathrm{SH} 21 \mathrm{~B}$ 의 첨가에 의해 4 일째부 
터 유의하게 증가되었다(Fig. 4A). 또 다른 지방세포형성 억제조 절자인 $\mathrm{CHOP}$ 은 $\mathrm{C} / \mathrm{EBP} \beta$ 단백질과 이질이합체(heterodimer)를 형성함으로써 그 활성을 억제한다고 알려져 있다[3]. 본 연구 에서 $\mathrm{CHOP}$ 의 $\mathrm{mRNA}$ 발현은 분화 초기(2일)에 크게 감소되 었다가 SH21B의 첨가에 의해 유의하게 증가되었다(Fig. $4 \mathrm{~B})$.
$\mathrm{CHOP}$ 의 기능은 $\mathrm{C} / \mathrm{EBP} \beta$ 발현 보다는 그 활성을 조절하는 것 이기 때문에, $\mathrm{SH} 21 \mathrm{~B}$ 에 의한 $\mathrm{CHOP}$ 의 mRNA 발현 증가 결과 는 $\mathrm{SH} 21 \mathrm{~B}$ 에 의해 변화가 없던 $\mathrm{C} / \mathrm{EBP \beta}$ 의 결과(Fig. $3 \mathrm{~A})$ 와 $\mathrm{SH} 21 \mathrm{~B}$ 에 의해 억제되었던 $\mathrm{PPAR} \gamma$ 의 결과(Fig. $2 \mathrm{~A}$ )에 적용 및 설명할 수 있다. 이러한 결과들은 SH21B가 지방세포형성

\section{Pro-adipogenic regulators}
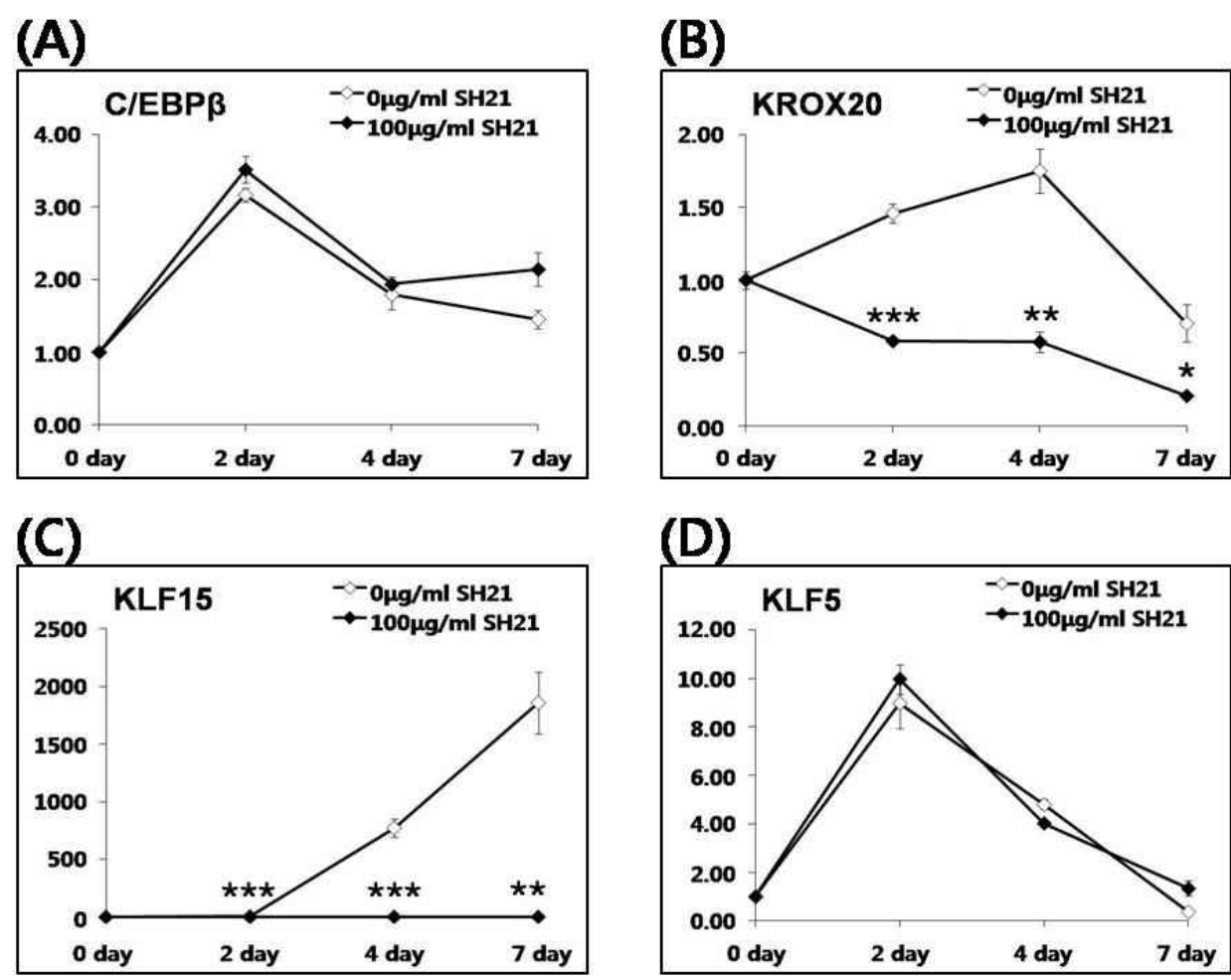

Fig. 3. Effects of SH21B on pro-adipogenic regulators located in the upstream of C/EBPa and PPAR $\gamma$. mRNA expression of C/EBP $\beta$ (A), KROX20 (B), KLF15 (C) and KLF5 (D) in 3T3-L1 cells differentiated for 0, 2, 4 and 7 day with or without $100 \mu \mathrm{g} / \mathrm{ml} \mathrm{SH} 21 \mathrm{~B}$ treatment. ${ }^{*} p<0.05,{ }^{* *} p<0.01,{ }^{* * *} p, 0.001$ compared with untreated adipocytes.

\section{Anti-adipogenic regulators}

(A)

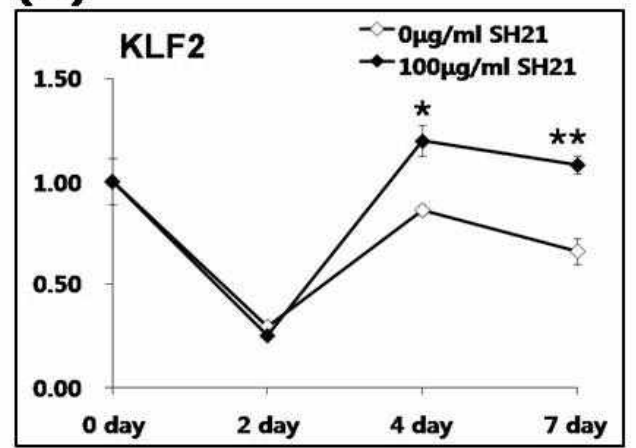

(B)

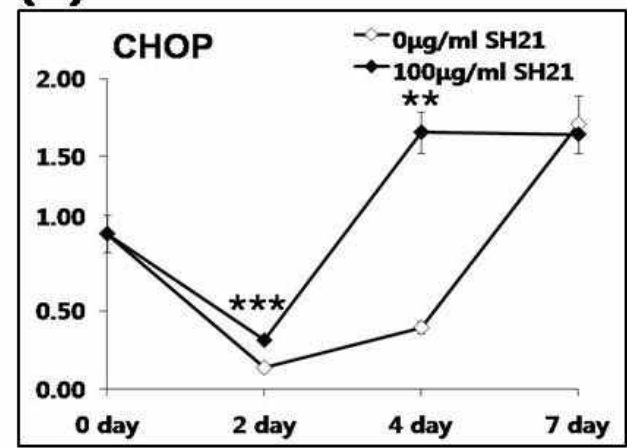

Fig. 4. Effects of SH21B on anti-adipogenic regulators located in the upstream of C/EBPa and PPAR $\gamma$. mRNA expression of KLF2 (A) and CHOP (B) in 3T3-L1 cells differentiated for 0, 2, 4 and 7 day with or without $100 \mathrm{\mu g} / \mathrm{ml} \mathrm{SH21B} \mathrm{treatment.}$ ${ }^{*} p<0.05,{ }^{* *} p<0.01,{ }^{* * *} p, 0.001$ compared with untreated adipocytes. 
억제조절자인 KLF2와 $\mathrm{CHOP}$ 의 $\mathrm{mRNA}$ 발현을 조절하여 하위 에 위치한 PPAR $\gamma$ 와 $\mathrm{C} / \mathrm{EBPa}$ 의 mRNA 발현을 억제함으로 써 지방세포형성을 저해함을 제시한다.

본 연구를 통해 $\mathrm{SH} 21 \mathrm{~B}$ 에 의한 지방세포형성 억제효능 및 adipogenesis를 조절하는 인자들의 mRNA 발현 변화를 확인 할 수 있었다. SH21B의 지방세포형성 억제효능은 Krox20, $\mathrm{KLF} 15$ 와 같은 지방세포형성 유도조절자와 $\mathrm{KLF} 2, \mathrm{CHOP}$ 과 같 은 지방세포형성 억제조절자의 mRNA 발현을 조절함으로써 나타났다. SH21B에 의해 변화된 다양한 상위조절자들의 $\mathrm{mRNA}$ 발현은 서로 상호작용하여 결국, 지방세포형성의 핵심 전사인자인 $\mathrm{PPAR} \gamma$ 와 $\mathrm{C} / \mathrm{EBPa}$ 의 $\mathrm{mRNA}$ 발현을 억제하고 이를 통해 지방세포형성의 최종마커인 ADIPOQ나 GLUT4의 $\mathrm{mRNA}$ 발현을 감소시켰다. 결론적으로, $\mathrm{SH} 21 \mathrm{~B}$ 에 의한 지방 세포형성 억제효능은 핵심전사인자를 포함한 다양한 지방세 포형성 조절자의 $\mathrm{mRNA}$ 발현이 복합적으로 조절되면서 나타 나는 것으로 사료된다.

\section{감사의 글}

본 연구는 보건복지가족부의 한의약선도기술개발사업 (B080020) 및 농촌진훙청의 바이오그린 21사업(20070301034-031)의 지원으로 이루어진 결과이며 이에 감사드립니다.

\section{References}

1. Ahmed, W., O. Ziouzenkova, J. Brown, P. Devchand, S. Francis, M. Kadakia, T. Kanda, G. Orasanu, M. Sharlach, F. Zandbergen, and J. Plutzky. 2007. PPARs and their metabolic modulation: new mechanisms for transcriptional regulation? J. Intern. Med 262, 184-198.

2. Chen, Z., J. I. Torrens, A. Anand, B. M. Spiegelman, and J. M. Friedman. 2005. Krox20 stimulates adipogenesis via C/EBPbeta-dependent and -independent mechanisms. Cell Metab. 1, 93-106.

3. Darlington, G. J., S. E. Ross, and O. A. MacDougald. 1998. The role of C/EBP genes in adipocyte differentiation. J. Biol. Chem 273, 30057-30060.

4. Freytag, S. O., D. L. Paielli, and J. D. Gilbert. 1994. Ectopic expression of the CCAAT/enhancer-binding protein alpha promotes the adipogenic program in a variety of mouse fibroblastic cells. Genes Dev. 8, 1654-1663.

5. Gray, S., M. W. Feinberg, S. Hull, C. T. Kuo, M. Watanabe, S. Sen-Banerjee, A. DePina, R. Haspel, and M. K. Jain. 2002. The Kruppel-like factor KLF15 regulates the insulin-sensitive glucose transporter GLUT4. J. Biol. Chem 277, 3432234328.

6. Gustafson, B. and U. Smith. 2006. Cytokines promote Wnt signaling and inflammation and impair the normal differentiation and lipid accumulation in 3T3-L1 preadipocytes. J. Biol. Chem 281, 9507-9516.

7. Hamm, J. K., A. K. el Jack, P. F. Pilch, and S. R. Farmer.
1999. Role of PPAR gamma in regulating adipocyte differentiation and insulin-responsive glucose uptake. Ann. $N Y$ Acad Sci. 892, 134-145.

8. Kaczynski, J., T. Cook, and R. Urrutia. 2003. Sp1- and Kruppel-like transcription factors. Genome Biol. 4, 206.

9. Kadowaki, T., T. Yamauchi, N. Kubota, K. Hara, K. Ueki, and $K$. Tobe. 2006. Adiponectin and adiponectin receptors in insulin resistance, diabetes, and the metabolic syndrome. J. Clin. Invest 116, 1784-1792.

10. Koerner, A., J. Kratzsch, and W. Kiess. 2005. Adipocytokines: leptin--the classical, resistin--the controversical, adiponectin-the promising, and more to come. Best Pract. Res. Clin. Endocrinol. Metab. 19, 525-546.

11. Lee, H., R. Kang, and Y. Yoon. 2009. SH21B, an anti-obesity herbal composition, inhibits fat accumulation in 3T3-L1 adipocytes and high fat diet-induced obese mice through the modulation of the adipogenesis pathway. J. Ethnopharmacol. DOI:10.1016/j.jep.2009.12.002

12. Lin, F. T. and M. D. Lane. 1994. CCAAT/enhancer binding protein alpha is sufficient to initiate the 3T3-L1 adipocyte differentiation program. Proc. Natl. Acad Sci. USA 91, 8757-8761.

13. Livak, K. J. and T. D. Schmittgen. 2001. Analysis of relative gene expression data using real-time quantitative PCR and the 2(-Delta Delta C(T)) Method. Methods 25, 402-408.

14. Medina-Gomez, G., S. Virtue, C. Lelliott, R. Boiani, M. Campbell, C. Christodoulides, C. Perrin, M. Jimenez-Linan, M. Blount, J. Dixon, D. Zahn, R. R. Thresher, S. Aparicio, M. Carlton, W. H. Colledge, M. I. Kettunen, T. Seppanen-Laakso, J. K. Sethi, S. O'Rahilly, K. Brindle, S. Cinti, M. Oresic, R. Burcelin, and A. Vidal-Puig. 2005. The link between nutritional status and insulin sensitivity is dependent on the adipocyte-specific peroxisome proliferatoractivated receptor-gamma2 isoform. Diabetes 54, 1706-1716.

15. Mori, T., H. Sakaue, H. Iguchi, H. Gomi, Y. Okada, Y. Takashima, K. Nakamura, T. Nakamura, T. Yamauchi, N. Kubota, T. Kadowaki, Y. Matsuki, W. Ogawa, R. Hiramatsu, and M. Kasuga. 2005. Role of Kruppel-like factor 15 (KLF15) in transcriptional regulation of adipogenesis. J. Biol. Chem 280, 12867-12875.

16. Morrison, R. F. and S. R. Farmer. 2000. Hormonal signaling and transcriptional control of adipocyte differentiation. $J$. Nutr. 130, 3116S-3121S.

17. Morrison, R. F. and S. R. Farmer. 1999. Role of PPARgamma in regulating a cascade expression of cyclin-dependent kinase inhibitors, p18(INK4c) and p21(Waf1/Cip1), during adipogenesis. J. Biol. Chem 274, 17088-17097.

18. Nawrocki, A. R. and P. E. Scherer. 2005. Keynote review: the adipocyte as a drug discovery target. Drug Discov. Today 10, 1219-1230.

19. Oishi, Y., I. Manabe, K. Tobe, K. Tsushima, T. Shindo, K. Fujiu, G. Nishimura, K. Maemura, T. Yamauchi, N. Kubota, R. Suzuki, T. Kitamura, S. Akira, T. Kadowaki, and R. Nagai. 2005. Kruppel-like transcription factor KLF5 is a key regulator of adipocyte differentiation. Cell Metab. 1, 27-39. 20. Rosen, E. D. and O. A. MacDougald. 2006. Adipocyte differ- 
entiation from the inside out. Nat. Rev. Mol. Cell Biol. 7, 885-896.

21. Shao, D. and M. A. Lazar. 1997. Peroxisome proliferator activated receptor gamma, CCAAT/enhancer-binding protein alpha, and cell cycle status regulate the commitment to adipocyte differentiation. J. Biol. Chem 272, 21473-21478.

22. Shepherd, P. R. and B. B. Kahn. 1999. Glucose transporters and insulin action--implications for insulin resistance and diabetes mellitus. N. Engl. J. Med. 341, 248-257.

23. Spiegelman, B. M. and J. S. Flier. 2001. Obesity and the regulation of energy balance. Cell 104, 531-543.

24. Takano, H. and I. Komuro. 2009. Peroxisome proliferatoractivated receptor gamma and cardiovascular diseases. Circ.
J. 73, 214-220.

25. Tanaka, T., N. Yoshida, T. Kishimoto, and S. Akira. 1997. Defective adipocyte differentiation in mice lacking the C/EBPbeta and/or C/EBPdelta gene. EMBO. J. 16, 74327443.

26. Tontonoz, P., E. Hu, and B. M. Spiegelman. 1994. Stimulation of adipogenesis in fibroblasts by PPAR gamma 2, a lipid-activated transcription factor. Cell 79, 1147-1156.

27. Zhang, J., M. Fu, T. Cui, C. Xiong, K. Xu, W. Zhong, Y. Xiao, D. Floyd, J. Liang, E. Li, Q. Song, and Y. E. Chen. 2004. Selective disruption of PPARgamma 2 impairs the development of adipose tissue and insulin sensitivity. Proc. Natl. Acad Sci. USA 101, 10703-10708.

\section{초록 : 생약복합물에 의한 지방세포형성 조절자의 유전자 발현 연구}

이해용 · 강련화 · 배성민 · 채수안 ${ }^{1} \cdot$ 이정주 ${ }^{1}$ - 오동진 ${ }^{2} \cdot$ 박석원 $^{3} \cdot$ 조수현 $4^{4} \cdot$ 심예지 ${ }^{5}$ 윤유식*

(중앙대학교 의과대학 미생물학교실, ${ }^{1}$ 소아과학교실, ${ }^{2}$ 내과학교실, ${ }^{3}$ 방사선종양학과, ${ }^{4}$ 가정의학과,

${ }^{5}$ 서울여자대학교 교양학부)

본 연구의 목적은 생약복합제제인 SH21B의 adipogenesis 억제 효능에 대한 상세한 분자적 메커니즘을 3T3-L1 지방세포를 이용하여 밝히는 데 있다. 실험에 사용된 SH21B는 7 가지 생약성 천연물질인, 황금, 행인, 마황, 석창 포, 포황, 원지 및 하엽으로 이루어졌다. 최근, 본 연구진에 의해 3T3-L1을 이용한 in vitro연구와 마우스를 이용한 in vivo 연구에서 SH21B의 adipogenesis 억제효능이 밝혀진 바 있다. 본 연구에서는 3T3-L1 지방세포가 분화될 때 작용하는 다양한 지방세포형성 조절자들의 유전자 발현이 $\mathrm{SH} 21 \mathrm{~B}$ 에 의해 어떻게 변하는지 살펴보고자 하였다. 실시간중합효소반응(real time PCR) 기술을 이용하여 SH21B를 처리한 지방세포와 그렇지 않은 지방세포를 비교 한 결과, 최종마커인 $\mathrm{ADIPOQ}$ 와 SLC2A4의 유전자 발현이 SH21B에 의해 급격하게 감소함을 알 수 있었다. 최종 마커의 발현을 유도하는 핵심전사인자인 $\mathrm{PPAR} \gamma$ 와 $\mathrm{C} / \mathrm{EBPa}$ 의 유전자 발현 역시 $\mathrm{SH} 21 \mathrm{~B}$ 의 처리 시 유의하게 억 제되었다. 좀 더 상세한 분자적 메커니즘을 규명하기 위해, 핵심전사인자의 상위에 위치한 다양한 조절자들의 유전자 발현을 분석하였다. 그 결과, 여러 지방세포형성 유도조절자 중, Krox20과 KLF15의 유전자 발현이 SH21B 처리에 의해 유의하게 감소된 반면, C/EBP $\beta$ 와 KLF5의 유전자 발현은 SH21B 처리에 영향을 받지 않았다. 그리 고 지방세포형성 억제조절자인 KLF2와 $\mathrm{CHOP}$ 의 유전자 발현은 SH21B 처리에 의해 유의하게 증가되었다. 이러 한 결과들은 $\mathrm{SH} 21 \mathrm{~B}$ 의 지방세포형성 억제효능이 지방세포의 분화에 작용하는 다양한 상위조절자 중 지방세포형 성 유도조절자인 Krox20과 KLF15 그리고 지방세포형성 억제조절자인 KLF2와 CHOP 등의 유전자 발현이 변화 되면서 일어나는 복합적인 반응의 결과임을 제시한다. 